\title{
COMPARATIVE STUDY BETWEEN N,N'-BIS (ACETYLACETONE)-O-PHENYLENEDIAMINE AND (MONOACETYLACETONE)-O-PHENYLENEDIAMINE SCHIFF BASE COMPLEXES
}

\author{
AMINA A.SOAYED* AND HEBA M.REFAAT \\ Chemistry Department, Faculty of Science, Alexandria University, Egypt. \\ P.O. Box 426-Ibrahimia, Alexandria 21321, Egypt. Fax: +2033911794
}

(Received: September 25, 2012 - Accepted: January 12, 2013)

\begin{abstract}
$\mathrm{Co}(\mathrm{II}), \mathrm{Ni}(\mathrm{II})$ and $\mathrm{Cu}(\mathrm{II})$ complexes formed from the Sciff base [ (2Z,4Z)-4-[(2-aminophenyl)imino-]pent-2-en-2-ol], were prepared in situ and characterized on the basis of elemental analyses, magnetism, UV-vis., IR and ESR spectra. Thermal analyses of the complexes were studied in order to confirm the proposed structures and determine their thermal stability. Comparison between geometries, ESR and thermal studies obtained from direct condensation and in situ preparation of complexes were discussed. The in situ data show that the Schiff base form complexes with 1:1 (metal : ligand) stoichiometry with Cu(II) and Ni(II) ions compared to 2:1 (metal : ligand) formed from direct condensation between schiff base and metal ions. However, the Co(II) in situ complex formed 1:2 (metal: ligand ) stoichiometry. Square-planar geometry was suggested for the $\mathrm{Cu}(\mathrm{II})$ and $\mathrm{Ni}(\mathrm{II})$ in situ complexes, while, octahedral geometry was suggested for the $\mathrm{Co}(\mathrm{II})$ complex. The ESR spectrum of the in situ $\mathrm{Cu}$ (II) complex was isotropic to suggest a geometry involving grossly misaligned tetragonal axes .The thermal behavior of the complexes showed good agreement with the formulae suggested from the analytical data. Thermal decomposition of the complexes took place in several stages. The order of stability was $\left[\mathrm{Cu} \mathrm{L} .\left(\mathrm{H}_{2} \mathrm{O}\right)\right] 3 \mathrm{H}_{2} \mathrm{O}>\mathrm{NiL} \cdot \mathrm{H}_{2} \mathrm{O}>\mathrm{CoL}_{2} \cdot \mathrm{H}_{2} \mathrm{O}$. The thermodynamic parameters , energy of activation $\Delta \mathrm{E}{ }^{*}$, enthalpy of activation $\Delta \mathrm{H}^{*}$, order of reaction $\mathrm{n}$ and entropy of activation $\Delta \mathrm{S}^{*}$ of the complexes were calculated. All the reactions were found to be first order. The high values of activation energies reveal the high stability of these complexes.
\end{abstract}

Key words: Schiff-base, IR, UV-Vis., ESR, TG, DTA.

\section{INTRODUCTION}

The chelating abilities of Schiff bases and their analytical applications have attracted remarkable attention [1-5]. o- Phenylene diamine (o-PDA) is used in the copper catalytized synthesis of quinoxalines [6]. o-PDA is also suitable for removing elemental sulfur in mining ores, and removing aldehyde color formers in polymers. Polymeric plasticized membrane electrode based on Bis(o-phenylenediamine)-Cu(II) (Cu(II)BOPD) complex has been investigated as iodide selective electrode exhibiting anti-Hofmeister selectivity pattern [7]. Moreover, it is used as a pharmaceutical intermediate in pharmaceuticals industry [8]. Schiff bases of (o-PDA) are used in the synthesis of insecticides, dyestuff fungicides, corrosion inhibitors and pigments. A large number of Schiff bases and their complexes are of significant interest and attention are drawn to them because of their biological activity including anti-tumor, antibacterial, fungicidal and anti-carcinogenic properties [1,9] .

The wide range of uses of o-PDA and its Schiff bases urged us to study its Schiff base with acetyl acetone by using a different method of preparation, the in situ method, which was successfully performed by others [10], in order to throw light on the structure, mode of bonding, spectral and thermal properties of this type of compounds and to compare between this study and previous studies.

\section{EXPERIMENTAL}

All the chemicals and solvents used for the syntheses were reagent grade. All solvents were dried and purified before being used. Elemental analyses $(\mathrm{C}, \mathrm{H}, \mathrm{N})$ were performed by the Micro analytical unit at Cairo University using using HP Model MS-5988. The metal ion content was determined using atomic absorption spectrophotometer 850-Fisher Jarrell ash computer controlled. Infrared spectra were recorded on a Perkin-Elmer FT-IR type 1650 spectrophotometer in wavenumber region $4000-200 \mathrm{~cm}^{-1}$. The spectra were recorded as KBr pellets.. The nujol mull electronic absorption spectra in the 200$1000 \mathrm{~nm}$ range were obtained using a Shimadzo AA-6800 spectrophotometer. The thermo-gravimetric analyses (TGA and DTA) was carried out in a dynamic nitrogen atmosphere $\left(20 \mathrm{~mL} \cdot \mathrm{min}^{-1}\right)$, with a heating rate of $10^{\circ} \mathrm{C} \mathrm{min}{ }^{-1}$ using LINSELS STA PT 1000 thermal analyzer. The ESR (X-band) spectrum for the poly-crystalline sample was recorded at room temperature using a Varian E-12 spectrometer and DPPH as an external standard.

Preparation of the Schiff base ligand:

(monoacetylacetone-o-phenylenediamine

Schiff base)
The ligand $\left(\mathrm{C}_{11} \mathrm{H}_{14} \mathrm{~N}_{2} \mathrm{O}\right)$ was prepared by condensation of $0.108 \mathrm{~g}(1.00$ mmol) o-phenylenediamine dissolved in $\mathrm{EtOH}$ to $0.100 \mathrm{~g}(1.00 \mathrm{mmol})$ of acetyl acetone dissolved in EtOH solvent and the reaction mixture stirred for $3 \mathrm{~h}$ at $60^{\circ} \mathrm{C}$. A brown precipitate was separated, filtered, washed several times with ethanol and dried in vacuum (m.p. $150^{\circ} \mathrm{C}$ ).<smiles>C/C(O)=C/C(C)=C/Nc1ccccc1N</smiles>

(mono acetylacetone-o-phenylenediamine Schiff base)

\section{Preparation of the metal complexes}

All the complexes were prepared in situ using the following method. To a $0.108 \mathrm{~g}(1.00 \mathrm{mmol})$ of the o-phenylenediamine dissolved in $30 \mathrm{~mL}$ of EtOH was added a solution of $0.100 \mathrm{~g}(1.00 \mathrm{mmol})$ of acetylacetone dissolved in 30 $\mathrm{mL} \mathrm{EtOH}$ and the reaction mixture was refluxed for 1hour. A $(1.00 \mathrm{mmol})$ of the metal salts $\mathrm{Cu}(\mathrm{AcO})_{2} \cdot \mathrm{H}_{2} \mathrm{O}, 0.20 \mathrm{~g}, \mathrm{CoCl}_{2} \cdot 6 \mathrm{H}_{2} \mathrm{O} 0.24 \mathrm{~g}$ and $\mathrm{Ni}(\mathrm{OAc})_{2} \cdot 4 \mathrm{H}_{2} \mathrm{O}$ , $0.25 \mathrm{~g}$ in $15 \mathrm{ml}$ ethanol was added drop wise with continuous stirring. The mixtures were stirred further for $1.5-2.5 \mathrm{~h}$. at $80^{\circ} \mathrm{C}$. The precipitated solids were then filtered off, washed with cold ethanol, followed by diethylether and dried in vacuum desiccators.

The colors and elemental analyses of all the compounds are presented in Table 1.

\section{RESULTS AND DISCUSSION}

\section{Infrared spectra}

In order to clarify the mode of bonding and the metal ion effect on ligand, the IR spectra of the free ligand and its metal chelates were studied, Figure 1, Table 2. FT-IR spectrum of the ligand revealed absorption bands in the region of stretching vibrations of $\mathrm{O}-\mathrm{H}$ and $\mathrm{N}-\mathrm{H}$ bonds. Thus, the absorption band at $3449 \mathrm{~cm}^{-1}$ was assigned to O-H bond [11] while the absorption band at 3396 $\mathrm{cm}^{-1}$ was assigned to a free $\mathrm{NH}_{2}$ group, which depicts the condensation of one acetyl acetone molecule ( and not two molecules ) to phenylene-diamine, thus forming monoacetylacetone-o-phenylenediamine Schiff base (I). The Schiff base ligand is characterized by strong bands at 1634 and $1298 \mathrm{~cm}^{-1}$ which are ascribed to the stretching vibrations of $\mathrm{C}=\mathrm{N}$ (imine) and $\mathrm{C}-\mathrm{O}$ groups, respectively $[12,13]$, beside bands at 1430 and $1264 \mathrm{~cm}^{-1}$ which are attributed 
to $-\mathrm{OH}$ bending $[12,14]$. The out-of-plane $\mathrm{C}-\mathrm{H}$ deformation of the phenyl ring was observed at $756 \mathrm{~cm}^{-1}$ [14]. Comparing the IR spectrum of Schiff base ligand prepared by that prepared by Sadek et.al [9] and Ismail et.al [15] where there was a lack of $\mathrm{NH}_{2}$ band and thus attributed to the formation of (N,N'-bis (acetylacetone)-o-phenylenediamine) and behaving as a dianionic tetradentate ligand [15].

Table 1. Elemental analyses of the metal complexes.

\begin{tabular}{|c|c|c|c|c|}
\hline \multirow[t]{2}{*}{ Complexes } & \multicolumn{4}{|c|}{$\begin{array}{c}\text { Elemental Analyses Calculated } \\
\text { (Found) } \%\end{array}$} \\
\hline & C & $\mathrm{H}$ & $\mathrm{N}$ & $\% \mathrm{M}$ \\
\hline $\begin{array}{c}{\left[\mathrm{CuL} .\left(\mathrm{H}_{2} \mathrm{O}\right)\right] 3 \mathrm{H}_{2} \mathrm{O}} \\
\mathrm{C}_{11} \mathrm{H}_{20} \mathrm{~N}_{2} \mathrm{O}_{4} \mathrm{Cu} \\
(\text { Brown })\end{array}$ & $\begin{array}{c}40.798 \\
(41.022)\end{array}$ & $\begin{array}{c}6.182 \\
(5.901)\end{array}$ & $\begin{array}{c}8.654 \\
(8.907)\end{array}$ & $\begin{array}{l}19.638 \\
(20.026)\end{array}$ \\
\hline $\begin{array}{c}{\left[\mathrm{CoL}_{2} \cdot \mathrm{H}_{2} \mathrm{O}\right]} \\
\mathrm{C}_{22} \mathrm{H}_{26} \mathrm{~N}_{4} \mathrm{O}{ }_{3} \mathrm{Co} \\
\text { (violet) }\end{array}$ & $\begin{array}{c}58.287 \\
(58.472)\end{array}$ & $\begin{array}{c}5.740 \\
(6.117)\end{array}$ & $\begin{array}{c}12.364 \\
(12.292)\end{array}$ & $\begin{array}{c}13.010 \\
(13.428)\end{array}$ \\
\hline $\begin{array}{c}{\left[\mathrm{NiL} . \mathrm{H}_{2} \mathrm{O}\right]} \\
\mathrm{C}_{11} \mathrm{H}_{14} \mathrm{~N}_{2} \mathrm{O}_{2} \\
\text { (green) }\end{array}$ & $\begin{array}{l}49.865 \\
(50.210)\end{array}$ & $\begin{array}{l}5.288 \\
(5.382)\end{array}$ & $\begin{array}{c}10.577 \\
(10.214)\end{array}$ & $\begin{array}{l}22.179 \\
(21.680)\end{array}$ \\
\hline
\end{tabular}

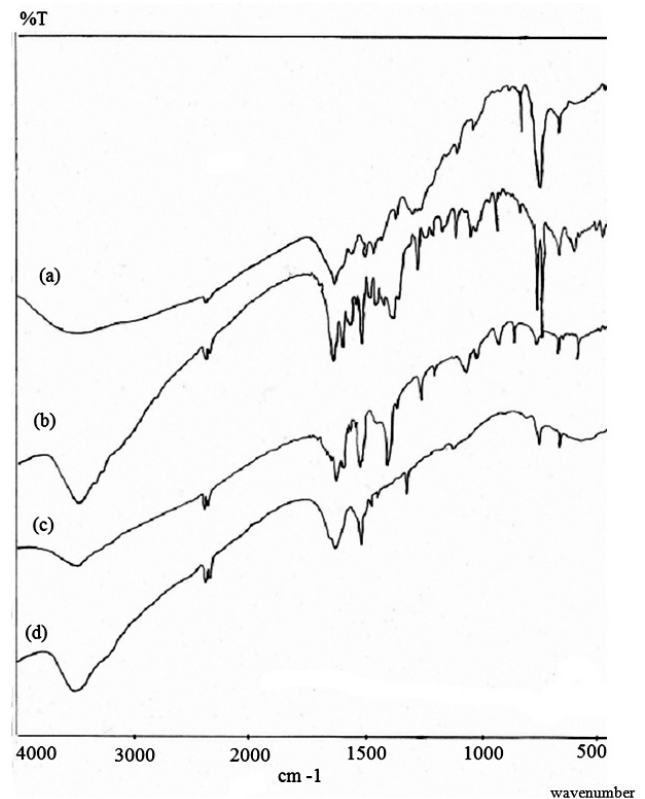

Figure (1): Infrared spectra of: (a) Ligand (c) $\left[\mathrm{NiL} . \mathrm{H}_{2} \mathrm{O}\right]$

(b) $\left[\mathrm{CoL}_{2} \cdot \mathrm{H}_{2} \mathrm{O}\right]$ (d) $\left[\mathrm{CuL} .\left(\mathrm{H}_{2}^{2} \mathrm{O}\right)\right] 3 \mathrm{H}_{2} \mathrm{O}$

Table (2). Characteristic IR and electronic absorption spectral data of the ligand and its metal complexes.

\begin{tabular}{|c|c|c|c|c|c|c|c|}
\hline Compound & $\begin{array}{c}v \mathbf{O}-\mathbf{H} \\
\mathbf{c m}^{-1}\end{array}$ & $\begin{array}{c}v \mathbf{N H}_{2} \\
\mathbf{c m}^{-1}\end{array}$ & $\begin{array}{c}v \mathbf{C}=\mathbf{N} \\
\mathbf{c m}^{-1}\end{array}$ & $\begin{array}{c}v \mathbf{C}-\mathbf{O} \\
\mathbf{c m}^{-1}\end{array}$ & $\begin{array}{c}v \mathbf{N}-\mathbf{H} \\
\text { bending } \\
\mathbf{c m}^{-1}\end{array}$ & $\begin{array}{c}v \text { M-O } \\
\text { or } \\
\text { M-N }\end{array}$ & $\lambda_{\text {max }}$ \\
\hline $\mathrm{L}$ & 3449 & 3396(b) & 1634 & 1298 & 1504 & - & - \\
\hline$\left[\mathrm{CuL} \cdot\left(\mathrm{H}_{2} \mathrm{O}\right)\right] \cdot 3 \mathrm{H}_{2} \mathrm{O}$ & $3460(b)$ & - & 1630 & 1322 & 1518 & $\begin{array}{l}364, \\
393\end{array}$ & 525 \\
\hline$\left[\mathrm{CoL}_{2} \cdot \mathrm{H}_{2} \mathrm{O}\right]$ & 3444 & - & $\begin{array}{l}1637 \\
1601\end{array}$ & 1278 & 1519 & $\begin{array}{l}356 \\
394\end{array}$ & $\begin{array}{c}513,635 \\
677\end{array}$ \\
\hline$\left[\mathrm{NiL} . \mathrm{H}_{2} \mathrm{O}\right]$ & 3448 & - & 1654 & 1256 & 1518 & $\begin{array}{l}364 \\
393\end{array}$ & $\begin{array}{c}430 \\
590\end{array}$ \\
\hline
\end{tabular}

The $\mathrm{Cu}(\mathrm{II}), \mathrm{Co}(\mathrm{II})$ and $\mathrm{Ni}(\mathrm{II})$ complexes gave broad bands at 3460, 3444 and $3448 \mathrm{~cm}^{-1}$ respectively, assigned either to coordinated water [16,17], or to $-\mathrm{OH}$ group, whereas, the band at $3396 \mathrm{~cm}^{-1}$ disappeared , together with the shifting of $v \mathrm{~N}-\mathrm{H}$ bending band from $1504 \mathrm{~cm}^{-1}$ in the ligand to $1518 \mathrm{~cm}^{-1}$ upon complexation indicating the contribution of the $\mathrm{NH}_{2}$ group in complex formation. Two $v \mathrm{C}=\mathrm{N}$ bands were observed in the $\mathrm{Co}$ (II) -complex, one of them is at about the same position as that in the ligand, whereas the second band is blue shifted indicating the coordination of one of the two $\mathrm{C}=\mathrm{N}$ groups of the two ligands to the metal ion. $v \mathrm{C}=\mathrm{N}$ band is red shifted in the $\mathrm{Ni}(\mathrm{II})-$ complex, also indicating its coordination to the metal ion. The $v \mathrm{C}-\mathrm{O}$ band at $1298 \mathrm{~cm}^{-1}$ is shifted to lower frequency by $\sim\left(20-42 \mathrm{~cm}^{-1}\right)$, thus it is suggested that the $-\mathrm{OH}$ group is deprotonated and oxygen atom of this (C-O) group is bonded to the metal ions. New bands in the ranges $356-420 \mathrm{~cm}^{-1}$ for the $\mathrm{Cu}, \mathrm{Co}$ and $\mathrm{Ni}$ complexes, due to $v \mathrm{M}-\mathrm{N}$ and $v \mathrm{M}-\mathrm{O}$ [18] were detected. The IR suggests that (mono acetylacetone-o-phenylenediamine ) coordinates to the metal ions in a tridentate fashion through $\mathrm{NNO}$; whereas $\mathrm{N}, \mathrm{N}^{\prime}$-bis (acetylacetone)-o-phenylenediamine coordinated through NNOO tetradentate mode [15]. Ismail et.al have shown that metal ions have coordinated to water, enolic $-\mathrm{OH}$ and $\mathrm{C}=\mathrm{N}$ (imino $\mathrm{N}$ atoms).

Electronic Absorption Spectra

The UV-visible absorption spectrum of the [CuL. $\left.\left(\mathrm{H}_{2} \mathrm{O}\right)\right] .3 \mathrm{H}_{2} \mathrm{O}$ prepared in situ, showed a band at $525 \mathrm{~nm}$ which may be assigned to ${ }^{2} \mathrm{~A}_{1} \rightarrow{ }^{2} \mathrm{~B}_{\text {g }}$ and is consistent with a square-planar $[19,20]$ or a distorted tetragonal $[21]$ geometry for this complex. The NiL. $\mathrm{H}_{2} \mathrm{O}$ showed two bands at 430 and $590 \mathrm{~nm}$ assigned as ${ }^{1} \mathrm{~A}_{1 \mathrm{~g}} \rightarrow{ }^{1} \mathrm{~B}_{\mathrm{gg}}$ and ${ }^{1} \mathrm{~A}_{\mathrm{gg}} \rightarrow{ }^{2} \mathrm{~A}_{2 \mathrm{~g}}$ attributed to the presence of this complex in the square-planar structure $[12,20,22]$. As for the cobalt complex $\mathrm{CoL}_{2} \cdot \mathrm{H}_{2} \mathrm{O}$, three bands were observed at 513,635 and $677 \mathrm{~nm}$ respectively assignable to the ${ }^{4} \mathrm{~T}_{1 \mathrm{~g}}(\mathrm{~F}) \rightarrow{ }^{4} \mathrm{~A}_{2 \mathrm{~g}}(\mathrm{~F})$ and ${ }^{4} \mathrm{~T}_{1 \mathrm{~g}}(\mathrm{~F}) \rightarrow{ }^{4} \mathrm{~T}_{2 \mathrm{~g}}(\mathrm{~F})[23]$ transitions in an octahedral structure. The $\mathrm{Ni}(\mathrm{II})$ complex reported in this work, is diamagnetic confirming consequently, four coordinate, square planar geometry [24,25] ruling out the presence of paramagnetic, tetrahedral form. The room temperature magnetic moments of the copper(II) complexes are expected to be higher than the spin-only value of 1.73 B.M. as a result of an orbital contribution and spinorbit coupling, which mixes in the higher terms into the ground term. As a result, 1.90-2.20 B.M. moment values are usually observed for mononuclear copper(II) complexes, regardless of stereo-chemistry [26] . A magnetic moment was found to be 1.884 B.M which lies within the expected value for one electron. The $\mathrm{Co}$ (II) complex has a magnetic moment of 5.12 B.M. corresponding to an octahedral geometry.

On the other hand, Ismail et.al [15], prepared complexes from N,N'bis(acetylacetone)-o-phenylenediamine having the $\left[\mathrm{Ni}_{2}\left(\mathrm{~L}^{2} \mathrm{Cl}_{2}\right] \cdot 2 \mathrm{H}_{2} \mathrm{O}(1)\right.$ and $\left[\mathrm{Cu}_{2}(\mathrm{~L})\left(\mathrm{H}_{2} \mathrm{O}\right)_{6}\right]\left(\mathrm{SO}_{4}\right)_{2} \cdot 2 \mathrm{H}_{2} \mathrm{O}(2)$ stoichiometries, assigning a tetrahedral, tetrahedral and octhedral geometries around $\mathrm{Ni}(\mathrm{II})$ and $\mathrm{Cu}(\mathrm{II})$ ions, respectively. From these data, it can be concluded that by changing the method of preparation, different structures are obtained.

Thermogravimetic (TGA) and differential thermal analysis (DTA):

Thermogravimetric (TG) and differential thermal analyses (DTA) for the metal complexes were carried out within the temperature range from 25-1000 ${ }^{\circ} \mathrm{C}$ at a heating rate of $10^{\circ} \mathrm{C} / \mathrm{min}$ in $\mathrm{N}_{2}$ atmosphere. It was noted that the thermal behaviour of $\mathrm{Co}(\mathrm{II}), \mathrm{Ni}(\mathrm{II})$ and $\mathrm{Cu}(\mathrm{II})$ complexes depends on the nature of the metal ion, Figure 2., Table 3.

The thermal behavior of the complexes showed good agreement with the formulae suggested from the analytical data, Table 3, Figure 2. The thermal decomposition of the complexes took place in several stages.

The TG curve of $\left[\mathrm{CuL}\left(\mathrm{H}_{2} \mathrm{O}\right)\right] .3 \mathrm{H}_{2} \mathrm{O}$ complex showed a mass loss of $16.300 \%$ (calc. $16.690 \%$ ) between $55-240{ }^{\circ} \mathrm{C}$ due to the loss of three water 
molecules in the first stage. Between the temperature $240-350{ }^{\circ} \mathrm{C}$, a percentage loss of 45.551 was observed (calculated $45.743 \%$ ) due to the loss of $\mathrm{C}_{8} \mathrm{H}_{6} \mathrm{~N}_{2}+$ the coordinated water molecule and the corresponding activation energy amounted to $103.925 \mathrm{KJ} / \mathrm{mol}$ and finally a percentage loss of 32.770 (calculated $33.00 \%$ ) due to the decomposition of the complex to $\mathrm{CuO}+2 \mathrm{C}$ in the temperature range $350-480^{\circ} \mathrm{C}$, , with corresponding activation energy amounting to $189.143 \mathrm{KJ} / \mathrm{mol}$. A remaining of $5.380 \%$ is attributed to the evolution of a $\mathrm{CH}_{4}$ molecule $(4.95 \%)$ during the process of decomposition.

Table (3): TGA of the studied complexes.

\begin{tabular}{|c|c|c|c|}
\hline Complex & $\mathbf{T} /{ }^{\circ} \mathbf{C}$ & $\begin{array}{c}\% \text { mass loss } \\
\text { Found (calc.) }\end{array}$ & Assignment \\
\hline$\left[\mathrm{CuL} .\left(\mathrm{H}_{2} \mathrm{O}\right)\right] 3 \mathrm{H}_{2} \mathrm{O}$ & $55-240$ & $16.300(16.690$ & $3 \mathrm{H}_{2} \mathrm{O}$ \\
\hline & $240-350$ & $45.551(45.743)$ & $\mathrm{C}_{8} \mathrm{H}_{6} \mathrm{~N}_{2}+\mathrm{H}_{2} \mathrm{O}$ \\
\hline & $350-480$ & $32.770(33.00)$ & $\mathrm{CuO}+2 \mathrm{C}$ \\
\hline$\left[\mathrm{CoL}_{2} \cdot \mathrm{H}_{2} \mathrm{O}\right]$ & $68-269$ & $28.030(27.150)$ & $\mathrm{C}_{6} \mathrm{H}_{5} \mathrm{~N}_{2}+\mathrm{H}_{2} \mathrm{O}$ \\
\hline & $269-450$ & $24.913(25.607)$ & $\mathrm{C}_{6} \mathrm{H}_{4} \mathrm{~N}_{2}+\mathrm{C}$ \\
\hline & $450-617$ & $46.720(47.365)$ & $\mathrm{Co}+\mathrm{C}_{8} \mathrm{H}_{16}+\mathrm{CO}_{2}$ \\
\hline & $204-289$ & $45.332(46.055)$ & $\mathrm{C}_{6} \mathrm{H}_{4} \mathrm{~N}_{2}+\mathrm{H}_{2} \mathrm{O}$ \\
\hline & $289-434$ & $38.380(38.840)$ & $\mathrm{NiO}_{2}+\mathrm{C}_{2} \mathrm{H}_{4}$ \\
\hline
\end{tabular}

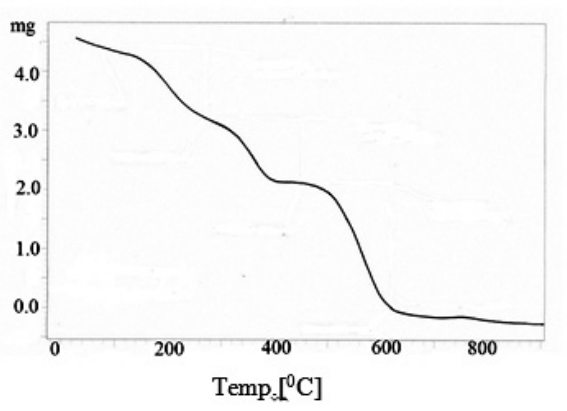

TG of $\left[\mathrm{CoL}_{2} \cdot \mathrm{H}_{2} \mathrm{O}\right]$

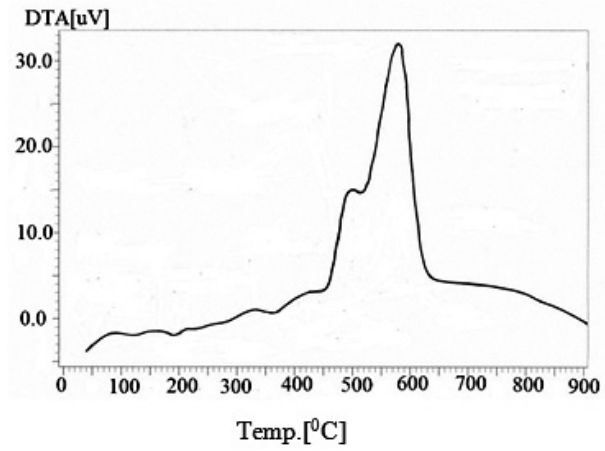

DTA of $\left[\mathrm{CoL}_{2} \cdot \mathrm{H}_{2} \mathrm{O}\right]$

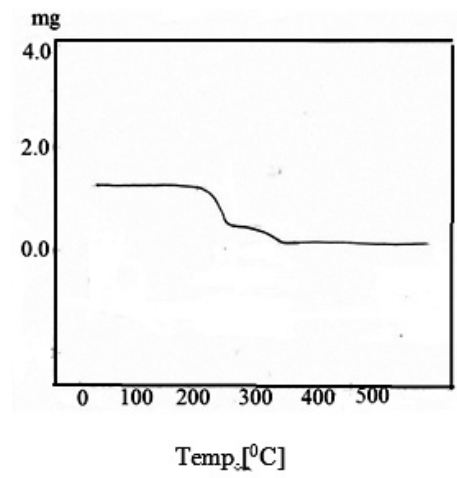

TG of [NiL. $\left.\mathrm{H}_{2} \mathrm{O}\right]$

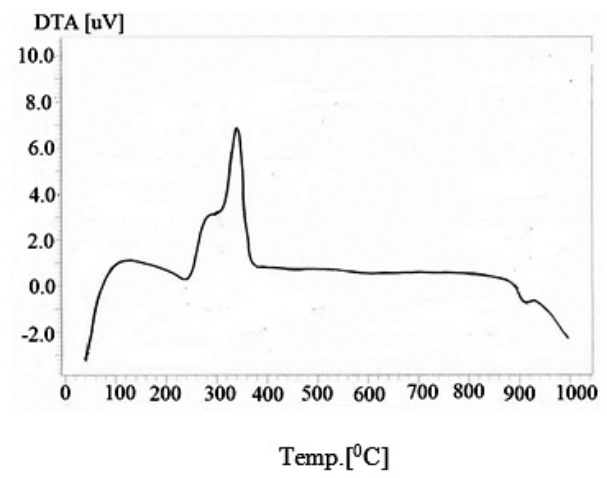

DTA of $\left[\mathrm{NiL} . \mathrm{H}_{2} \mathrm{O}\right]$

Figure (2): TGA and DTA of metal complexes

On the other hand, The TGA of $\mathrm{Cu}(\mathrm{II})$ complex $\left[\mathrm{Cu}_{2}(\mathrm{~L})\left(\mathrm{H}_{2} \mathrm{O}\right)_{6}\right]$ $\left(\mathrm{SO}_{4}\right)_{2} \cdot 2 \mathrm{H}_{2} \mathrm{O}(2)$ prepared by Ismail et.al [15] shows loss in weight within the temperature range $50-180{ }^{\circ} \mathrm{C}$, due to removal of the lattice and coordinated water molecules. The dehydrated complex is thermally stable up to $360^{\circ} \mathrm{C}$, after which $\mathrm{SO}_{4}{ }^{2-}$ ions were removed. Finally the complex undergoes decomposition of the organic ligand at $800{ }^{\circ} \mathrm{C}$, whereupon the final product $\left[\mathrm{Cu}_{2}(\mathrm{O})_{2}(\mathrm{CO})_{2}\right]$ is formed.

Comparing the decomposition pattern of the two different copper complexes, it seems that the latter complex is decomposed at a higher temperature due to its presence as a dimer.

The DTA of $\left[\mathrm{CuL}\left(\mathrm{H}_{2} \mathrm{O}\right)\right] \cdot 3 \mathrm{H}_{2} \mathrm{O}$ showed one broad splitted endothermic peak centered at 90 and $150^{\circ} \mathrm{C}$, together with two small exothermic peaks at 170 and $200{ }^{\circ} \mathrm{C}$ which is in accord with the dehydration of outer and decomposition of the coordinated water molecules. Two other strong exothermic peaks were observed at $325^{\circ} \mathrm{C}$ and $420{ }^{\circ} \mathrm{C}$ due to the decomposition of the rest of the complex.

The TG of [NiL. $\left.\mathrm{H}_{2} \mathrm{O}\right]$ showed the mass loss in two steps only. The first between $204-289^{\circ} \mathrm{C}$ owing to the loss of $\mathrm{C}_{6} \mathrm{H}_{4} \mathrm{~N}_{2}+$ coordinated $\mathrm{H}_{2} \mathrm{O}$ (found: $45.288 \%$, calculated: $46.055 \%$ ). The second step between the temperature range $289-434{ }^{\circ} \mathrm{C}$ attributed to the loss of $\mathrm{NiO}+\mathrm{C}_{2} \mathrm{H}_{4}$ molecule (found: 38.380 $\%$, calculated $38.840 \%)$. A $(16.338 \%)$ which is remaining is attributed to the evolution of $\mathrm{C}_{3} \mathrm{H}_{6}$ molecule (15.850\%).

The DTA curve exhibits two exothermic peaks. The first is at $117{ }^{\circ} \mathrm{C}$ is due to the loss of the coordinated water molecule to the $\mathrm{Ni}(\mathrm{II})$ ion $[27,28]$ 
together with the loss of part of the organic ligand. The second peak which is a splitted one centered at $210,240^{\circ} \mathrm{C}$ is due to the decomposition of the rest of the complex.

As for the cobalt complex $\mathrm{CoL}_{2} \cdot \mathrm{H}_{2} \mathrm{O}$, three steps were detected. In the first step, between $68-269^{\circ} \mathrm{C}$, the loss was found to be $28.030 \%$ (calculated: 27.150 $\%$ ) due to the loss of $\mathrm{C}_{6} \mathrm{H}_{5} \mathrm{~N}_{2}$ + the coordinated $\mathrm{H}_{2} \mathrm{O}$ molecule with activation energy $156.968 \mathrm{KJ} / \mathrm{mol}$. Then between $269-450{ }^{\circ} \mathrm{C}$, the $\%$ loss was found to be $24.983 \%$ (calculated $25.607 \%$ ) owing to the loss of the second $\mathrm{C}_{6} \mathrm{H}_{4} \mathrm{~N}_{2}+\mathrm{C}$ molecule, with an activation energy of $149.984 \mathrm{KJ} / \mathrm{mol}$. The third step between $450-617^{\circ} \mathrm{C}$ was attributed to the decomposition of the rest of the complex to $\mathrm{Co}+\mathrm{CO}_{2}+\mathrm{C}_{8} \mathrm{H}_{16}$ molecules, (found: $47.850 \%$, calculated $47.395 \%$ ) with activation energy $76.455 \mathrm{KJ} / \mathrm{mol}$.

The DTA of $\mathrm{CoL}_{2} . \mathrm{H}_{2} \mathrm{O}$ gave exothermic peaks at $80,150,220,340,425$, 510 and $680^{\circ} \mathrm{C}$ due to the decomposition of the complex [29].

There were no data available in the literature to compare between them and the prepared $\mathrm{Co}(\mathrm{II})$ and $\mathrm{Ni}$ (II) complexes.

From the DTA data, the thermodynamic parameters $\Delta \mathrm{E}^{*}$ (activation energy), $\Delta \mathrm{H}^{*}$ (enthalpy of activation), $\mathrm{n}$ (order of the reaction) and $\Delta \mathrm{S}^{*}$ (entropy) were calculated by the Horowitz-Metzger equations [30,31] and the results are shown in Table 4 . The values of the collision factor, $Z$, were calculated based on the following relation :

Table (4): Thermodynamic parameters of the complexes.

\begin{tabular}{|c|c|c|c|c|c|c|}
\hline Complex & $\mathrm{T}_{\mathrm{m}} / \mathrm{K}$ & $\mathrm{n}$ & $\begin{array}{c}\mathrm{Z} \\
\left(\mathrm{min}^{-1}\right)\end{array}$ & $\Delta \mathrm{E}_{\mathrm{a}}^{*}(\mathrm{KJ} / \mathrm{mol})$ & $\Delta \mathrm{H}^{*}(\mathrm{KJ} / \mathrm{molK})$ & $\begin{array}{c}\Delta \mathrm{S}^{*} \\
(\mathrm{KJ} / \mathrm{mol})\end{array}$ \\
\hline & 320 & 1.14 & 7.355 & 103.925 & -73.252 & -0.229 \\
\hline$\left[\mathrm{CuL} .\left(\mathrm{H}_{2} \mathrm{O}\right)\right] 3 \mathrm{H}_{2} \mathrm{O}$ & 400 & 1.47 & 10.928 & 189.143 & -90.990 & -0.228 \\
& 430 & 1.26 & 8.104 & 156.968 & -99.141 & -0.230 \\
\hline & 535 & 1.02 & 5.985 & 149.984 & -125.671 & -0.234 \\
\hline $\left.\mathrm{CoL}_{2} \cdot \mathrm{H}_{2} \mathrm{O}\right]$ & 610 & 1.19 & 2.575 & 76.455 & -148.230 & -0.243 \\
& 140 & 1.49 & 4.395 & 26.147 & -31.684 & -0.226 \\
\hline & 290 & 1.06 & 6.857 & 89.874 & -78.199 & -0.230 \\
& 340 & 1.54 & 7.064 & 104.34 & -66.244 & -0.228 \\
\hline
\end{tabular}

$\mathrm{Z}=\left(\Delta \mathrm{E}_{\mathrm{a} /}^{*} \mathrm{RT}_{\mathrm{m}}\right) \varphi \exp \cdot\left(\Delta \mathrm{E}_{\mathrm{a}}^{*} / \mathrm{RT}_{\mathrm{m}}{ }^{2}\right)=\mathrm{KT}_{\mathrm{m}} / \mathrm{h} \exp \left(\Delta \mathrm{S}^{*} / \mathrm{R}\right)$,

where $\mathrm{R}=$ molar gas constant, $\varphi=$ the rate of heating $(10 \mathrm{~K} / \mathrm{min}), \Delta \mathrm{S}^{*}=$ the entropy of activation, $\mathrm{K}$ and $\mathrm{h}$ are the Boltzman and Planck's constants, respectively. The change of the entropy $\Delta \mathrm{S}^{*}$ values for all complexes are of the same magnitude within the range

$(-0.226-0.243 \mathrm{KJ} / \mathrm{mol} \mathrm{K})$. The negative values for the entropies of activation indicate that the activated complexes have more ordered structure than the reactants and the reactions are slower than normal [32]. The negative values of $\Delta \mathrm{S}^{*}$ make the dissociation process non-spontaneous. All the reactions were found to be approximately first order. The high values of activation energies reveal the high stability of chelation in these complexes [33]. Comparing $\Delta \mathrm{E}_{2}$ of $\left[\mathrm{CuL}\left(\mathrm{H}_{2} \mathrm{O}\right)\right] .3 \mathrm{H}_{2} \mathrm{O}$ with that of $\left[\mathrm{NiL} . \mathrm{H}_{2} \mathrm{O}\right]$, it was found that the former possess a higher value, since as the radius of the metal ion decreases, the binding between it and the ligand increases. $\Delta \mathrm{E}_{\mathrm{a}}$ of the $\mathrm{Co}$ (II) complex is the greatest as two ligand molecules are coordinated to the metal ion. $\Delta \mathrm{H}$ values are negative, indicating exothermic decomposition processes.

Ismail et.al [15], have also shown that $\Delta \mathrm{S}^{*}$ values for $\left[\mathrm{Cu}_{2}(\mathrm{~L})\left(\mathrm{H}_{2} \mathrm{O}\right)_{6}\right]$ ( $\mathrm{SO})_{2} \cdot 2 \mathrm{H}_{2} \mathrm{O}$ complex were negative indicating that either the activated complex is more ordered than the reactants and/or the reactions are slow, whereupon, they obtained positive $\Delta \mathrm{H}^{*}$ values which means that the decomposition processes are endothermic.

\section{X-band EPR:}

The X-band EPR spectrum of the $\left[\mathrm{CuL}\left(\mathrm{H}_{2} \mathrm{O}\right)\right] \cdot 3 \mathrm{H}_{2} \mathrm{O}$ complex in the solidstate was measured at room temperature and gave a dissymmetric isotropic broad band having no hyperfine structure, Figure 3. When there is a slowmotion regime, the rotational diffusion is slow, so that the spectrum loses its similarity to the isotropic limiting case. The lines broaden and distort [34]. Also, the broadening can be due to dipolar exchange and unresolved hyperfine interactions in the solid state [35] or due to the tumbling motion of the molecules [36]. The calculated g.-value was found to be equal to 2.145 , Figure (2), to suggest a geometry involving grossly misaligned tetragonal axes [37]. $\mathrm{A}_{\mathrm{i}}=139 \times 10^{-4} \mathrm{~cm}^{-1}$. On the other hand, $\left[\mathrm{Cu}_{2}(\mathrm{~L})\left(\mathrm{H}_{2} \mathrm{O}\right)_{6}\right]\left(\mathrm{SO}_{4}\right)_{2} \cdot 2 \mathrm{H}_{2} \mathrm{O}(2)$ [15], prepared by Ismail et. al, gave two g-values, $\mathrm{g}_{1}>\mathrm{g} \square$ which indicates that the unpaired electron is predominantly in the $\mathrm{d}_{\mathrm{x} 2-\mathrm{y}_{2}}$ orbital giving ${ }^{2} \mathrm{~B}_{1 \mathrm{~g}}$ as the ground state. The observed data show that the $\mathrm{g}_{2}$ values are $>2.0023$ and hence the metal-ligand bonding in this complex is essentially covalent. Figure 4.

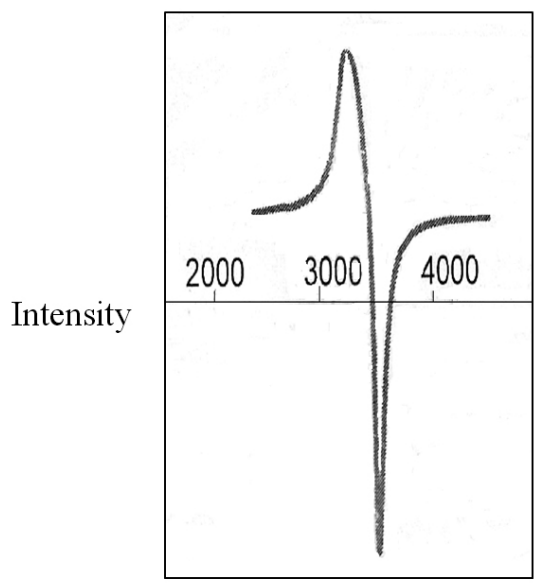

magnetic field (Gauss)

Figure (3) : X-band EPR spectrum of the $\left[\mathrm{CuL}\left(\mathrm{H}_{2} \mathrm{O}\right)\right] \cdot 3 \mathrm{H}_{2} \mathrm{O}$ complex in the solid-state.

\section{CONCLUSION}

1- Preparation of Schiff base and its complexes derived from o-phenylenediamine and acetylacetone were performed in situ in order to compare between them and those prepared previously by normal condensation method.

2- It was found that the in situ method gives (monoacetylacetone)-ophenylenediamine Schiff base compared to N,N'-bis (acetylacetone)-ophenylenediamine obtained by condensation method.

3- The activation energy for decomposing the in situ (mono) copper (II) complex is lower than that of the dimeric complex prepared by condensation which was expected due to the presence of two $\mathrm{Cu}(\mathrm{II})$ ions. 


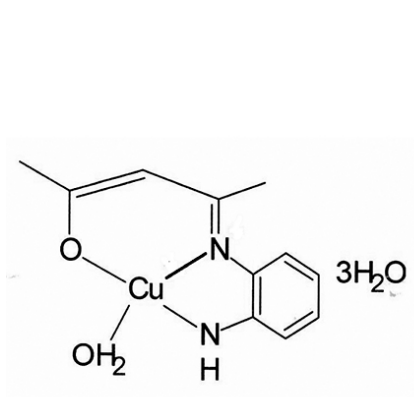

(a)

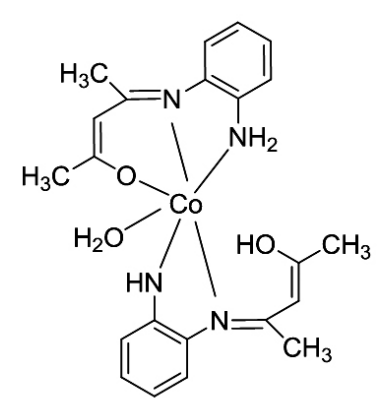

(b)<smiles>CC1=CC2=C(C)O[N+]3(O)Nc4ccccc4N2N13</smiles>

(c)

Figure (4): The proposed structures for complexes:
(a) [CuL. H2O $] .3 \mathrm{H} 2 \mathrm{O}$
(b) $[\mathrm{CoL} 2 . \mathrm{H} 2 \mathrm{O}]$
(c) $[\mathrm{NiL} . \mathrm{H} 2 \mathrm{O}]$

\section{REFERENCES}

1. N. Ramana., L.Mitub, A. Sakthivela , M.S.S. Pandia, J. Iran.Chem. Soc., 6(4) ,738, (2009).

2. A.S. Munde, A. Jagdale, S.M. Jadhav, T.K. Chondhekar, J. Serb. Chem. Soc., 75(3), 349, (2010).

3. B. Theis, S. Metz, F. Back, C. Burschka, R. Tacke, Z anorg. allg. Chem., 635, 1306 (2009).

4. B. Sindhukumari, G. Rijuulal, K. Mohanan, Synth. React. Inorg., Met.Org. Nano-Met. Chem., 39, 24, (2009).

5. M.B. Dai , Q.L. Zhang; X.C. Zhu, Y.Q. Zhang; B.X. Zhu, Wuji Huaxue Xuebao (Chin.J.Inorg.Chem.), 24, 1381, (2008).

6. W. Wang, Y. Shen, X. Meng, M. Zhao, Y. Chen, B. Chen, Org. Lett., 13(17), 4514, (2011)

7. A. Rawat, S. Chandra, A. Sarkar, Sensor Letters, 8(6), 753, (2010).

8. B.J. Gangani , P.H. Parsania , Spectrosc. Lett., 40 , 97, (2007).

9. S.A. Sadeek, M.S. Refaat., Journal of the Korean Chemical Society, 50(2) 107, (2006).

10. Y.Q Jiang, Z.H. Zhou, Z.B. Wei, JIEGOU HUAXUE, (Chinese J. Struct. Chem.) 24 (4), 457 (2005).

11. M. Jadrijevic, M. Takac, D.V. Topic, T. Govorcinovic, Acta Pharm., 54(3), 163, (2004).

12. R.L. De, M. Mandal, L. Roy, J. Mukherjee, R. Bhawal, K. Maiti, Indian Journal of Chemistry, 47(A), 1480, (2008).

13. M. Sonmez, Erciyes Üniversitesi Fen Bilimleri Enstitüsü Dergisi, , 24(12), 308, (2008).

14. M. Tumer, H. Koksal, S. Serin, M. Digrak., Trans.Met.Chem., 24, 13, (1999).

15. T.M.A. Ismail , A.A. Saleh, M.A. El Ghamry, Spectrochimica Acta Part A: Molecular and Biomolecular Spectroscopy, 86, 276, (2012).

16. M. Gaber, M.M. Ayad, Y.S.Y. El-Sayed, Spectrochim. Acta, A, 62, 694, (.2005).

17. B. Dede, F. Karipcin, M. Cengiz, J. Chem. Sci., 121(2), 163, (2009).

18. N. Raman, A. Kulandaisamy, C. Thangaraja, P. Manisankar, S. Viswanathan, C. Vedhi, Trans.Met.Chem, 29 (2), 129, (2004).

19. a) N. Gupta, R. Gupta, S. Chandra, S.S. Bawa, Spectrochim. Acta Part A, 61(6), 1175, (2005), (b) A.B.P. Lever , Inorganic Electronic Spectroscopy, 2nd ed.; Elsevier: Amsterdam, 1984.

20. A.A. Osowole, Bull. Chem. Soc. Ethiop., 22(2), 219, (2008).

21. S. karabocek, N. Karabocek, Polyhedron, 17, 319, (1998).

22. N. Raman, J.D. Raja, A. Sakthivel., J. Chem. Sci., 119(4), 303, (2007).

23. M. Sonmez, Turk. J. Chem., 25, 181, (2001).

24. M. Lashanizadegan, D.M. Boghaei., Synth. React. Inorg. Met.-Org. Chem.,
31, 1519, (2001).

25. A.A. Osowole, G.A. Kolawole, O.E. Fagade, Synth. React. Inorg. Met.Org. Chem. and Nano-Metal Chem., 35, 829, (2005).

26. A. Earnshaw , "The Introduction to Magnetochemistry", Academic Press: London; 1980.

27. S.L. Stefan, J. Thermal Analysis, 42, 1299, (1994)..

28. J.C. Pessoa, J.A.J. Silva, A.L. Vieira, L. Vilas-Boas, P.O. Brien, P. Thomton , J. Chem. Soc., Dalton Trans., 1745, (1992)..

29. A. Reiss A., S. Florea, T. Caproui , N. Stanic , Turk. J. Chem., 33 , 775, (2009).

30. H.H. Horowitz, G. Metzger, Anal. Chem., 35(10), 1464, (1963).

31. M,L. Dhar, O. Singh, J. Thermal Analysis, 37, 259, (1991) .

32. N. Raman ,S. Ravichandran, C. Thangaraja, J. Chem. Sci. , 116(4), 215, (2004).

33. M.S. Refat, J.Therm.Anal.Calorim, 102(3),1095, (2010).

34. S. Stoll ; A Schweiger, J Magn Reson, 178 , 42, (2006).

35. K.K. Narang, V.P. Singh, Transition Met. Chem., 21(6), 507, (1996)..

36. A.A. Frost, R.G. Pearson, Kinetics and Mechanism, 2nd edition, Wiley, New York, 1961.

37. V.P. Singh, P. Gupta, N. Lal, Russian Journal of Coordination Chemistry, 34(4), 270, (.2008). 